\title{
Pemberian Motivasi Belajar Di SMPN 2 Pare Kabupaten Kediri
}

\author{
Mohammad Ikhwan Khosasih* \\ STIKes Pamenang, Kediri, Indonesia \\ * ikhwankhosasih@gmail.com
}

\begin{abstract}
ABSTRAK
Proses belajar mengajar tidak bisa terlepas dari macam faktor yang dapat mempengaruhi dan menunjang keberlangsungannya. Salah satu penunjang utamanya adalah adanya motivasi belajar bagi peserta didik yang terstruktur dan terkonstruksi dengan baik. Metode dalam pengabmas ini menggunakan pre dan post motivasi. Pemberian motivasi berjalan dengan tertib dan lancar, hasil observasi post motivasi didapatkan sebagian besar yaitu 29 siswa aktif dalam mengikuti mata pelajaran selama 2 minggu (100\%), satu siswa dengan angka ketidakhadirannya sebesar 58,3\%. atau lima hari tidak masuk dalam dua minggu. Kegiatan berlangsung tepat sesuai jadwal yang telah kami buat, tahap evaluasi, siswa mengikuti jalannya pemberian motivasi dengan baik, siswa diberikan feedback tentang tanggungjawab sebagai pelajar, tugas-tugas sebagai pelajar dan rencana masa depan. Urgensi dari pada motivasi adalah sebagai pendorong, penggerak dan sebagai suatu pengaruh terhadap tujuan. Lembaga pendidikan, sebagai wadah tempat berkumpulnya agen-agen perubahan sosial dan segala perangkatnya, haruslah memiliki prinsip kebersamaan atau kerjasama yang baik antar lembaga dan anggota serta orangorang yang berkepentingan didalamnya, Pembelajaran yang efektif bukan membuat siswa menjadi pusing akan tetapi bagaimana tujuan pembelajaran dapat tercapai dengan mudah dan menyenangkan.
\end{abstract}

Kata Kunci: Motivasi belajar, Siswa SMP, Pre-Post

Received: June 8, 2020

Revised: June 28, 2020

Accepted: July 20, 2020

This is an open-acces article distributed under the terms of the Creative Commons Attribution-ShareAlike 4.0 International License.

\section{PENDAHULUAN}

Proses belajar mengajar tidak bisa terlepas dari macam faktor yang dapat mempengaruhi dan menunjang keberlangsungannya. Salah satu penunjang utamanya adalah adanya motivasi belajar bagi peserta didik yang terstruktur dan terkonstruksi dengan baik. Sebelum pemberian motivasi kami lakukan survey kepada siswa dengan berkoordinasi pada pihak guru BK (bimbingan konseling). Menurut hasil survei yang kami lakukan, kami mendapatkan data bahwa masih ada siswa yang bolos sekolah dan malas belajar, kondisi ini dikhawatirkan akan mempengaruhi siswa lainnya, oleh karena itu, sekolah memutuskan untuk memberikan motivasi belajar. Pembelajaran yang efektif bukan membuat siswa menjadi pusing akan tetapi bagaimana tujuan peambelajaran dapat tercapai dengan mudah dan menyenangkan. 


\section{Journal of Community Engagement in Health}

http://jceh.org

ISSN: 2620-3758 (print); 2620-3766 (online)

https://doi.org/10.30994/jceh.v3i2.65

Vol.3 No.2. Sep 2020. Page.189-193

Urgensi dari pada motivasi adalah sebagai pendorong, penggerak dan sebagai suatu pengaruh terhadap tujuan. Lembaga pendidikan,sebagai wadah tempat berkumpulnya agen-agen perubahan sosial dan segala perangkatnya, haruslah memiliki prinsip kebersamaan atau kerjasama yang baik antar lembaga dan anggota serta orang-orang yang berkepentingan didalamnya tanpa kerjasama yang baik, semua cita-cita yang menjadi tujuan dari lembaga pendidikan ibarat asap yang tebal akan tetapi mudah sirna dengan sendirinya. Luaran yang diharapkan adalah agar siswa lebih semangat dan bertanggung jawab dalam belajar dan aktif masuk sekolah, demi masa depan lebih baik.

Sasaran dalam kegiatan ini adalah siswa SMPN 2 Pare Kediri kelas VII berjumlah 30 siswa.

\section{BAHAN DAN METODE}

Metode pelaksanaan kegiatan dilakukan dengan pre dan post motivasi.

1. Pre motivasi

Meliputi persiapan kegiatan yang terdiri dari permohonan ijin, survei kelompok sasaran, persiapan sarana dan prasarana, ini di fasilitasi sepenuhnya pihak sekolah, kemudian dilakukan pemberian motivasi

2. Post motivasi

Kegiatan post motivasi dengan melakukan observasi berkoordinasi dengan guru BK selama 2 minggu.

\section{HASIL}

Data yang diperoleh dari survey didapatkan dari 30 siswa yang akan diberikan motivasi belajar

Tabel 1. Kehadiran siswa dikelas dalam mengikuti semua mata pelajaran sebelum motivasi selama 4 minggu / 24 hari efektif

\begin{tabular}{ccccc}
\hline No & Jumlah siswa & $\begin{array}{c}\text { tidak hadir } \\
\text { (hari) }\end{array}$ & Hadir (hari) & $\%$ \\
\hline 1 & 29 & - & 24 & 100 \\
\hline 2 & 1 & 7 & 17 & 70,8 \\
\hline
\end{tabular}

Tabel 1. memperlihatkan sebagian besar yaitu 29 siswa aktif dalam mengikuti mata pelajaran selama satu bulan terhitung 24 hari efektif (100\%), satu siswa dengan angka ketidakhadirannya sebesar $70,8 \%$ atau tidak mengikuti mata pelajaran selama tujuh hari dalam 4 minggu.

Pemberian motivaasi dilakukan pukul 13.30 WIB sampai dengan pukul 16.00 WIB dengan jumlah 30 siswa. Pemberian motivasi belajar ini dilakukan dengan ceramah dan tanya jawab dengan siswa. Tahap evaluasi, siswa mengikuti jalannya pemberian motivasi dengan baik, siswa diberikan feedback tentang tanggungjawab sebagai pelajar, tugas-tugas sebagai pelajar dan rencana masa depan. Hasil evaluasi sesaat pada motivasi, siswa mampu mengutarakan rencana merubah cara belajar dan berjanji melaksanakannya dengan tanggung jawab. Pemberian motivasi belajar diawali dengan perkenalan pemateri kepada siswa lalu dilanjutkan dengan pemberian materi motivasi dan tanya jawab. Kegiatan berlangsung tertib tidak ditemukan tanda - tanda perilaku siswa yang kurang tertib seperti bersikap kurang ajar, tidak sopan atau celometan, semua berjalan tertib, tepat sesuai jadwal yang telah kami buat, siswa mengikuti kegiatan pemberian motivasi dengan tertib dan lancar, tanya jawab antara siswa dengan pemateri juga berlangsung dengan lancar dalam suasana yang santai menyenangkan, siswa mampu mengutarakan rencana merubah cara belajar dan berjanji melaksanakannya dengan penuh tanggung jawab. 


\section{Journal of Community Engagement in Health}

http://jceh.org

ISSN: 2620-3758 (print); 2620-3766 (online)

https://doi.org/10.30994/jceh.v3i2.65

Vol.3 No.2. Sep 2020. Page.189-193

Setelah diberikan motivasi maka dievaluasi dan didapatkan hasil obersavi selama 2 minggu dengan guru BK sesuai tabel 2.

Tabel 2. Kehadiran siswa dikelas dalam mengikuti semua mata pelajaran setelah

motivasi selama 2 minggu/12 hari efektif

\begin{tabular}{ccccc}
\hline No & Jumlah siswa & $\begin{array}{c}\text { Tidak hadir } \\
\text { (hari) }\end{array}$ & Hadir (hari) & $\%$ \\
\hline 1 & 29 & - & 24 & 100 \\
\hline 2 & 1 & 5 & 19 & 58,3 \\
\hline
\end{tabular}

Tabel 2. memperlihatkan sebagian besar yaitu 29 siswa aktif dalam mengikuti mata pelajaran selama 2 minggu (100\%), satu siswa dengan angka ketidakhadirannya sebesar $58,3 \%$. atau lima hari tidak masuk dalam dua minggu.

Pemberian motivasi yang sudah dilakukan berjalan dengan tertib dan lancar, namun pada saat observasi post motivasi masih ditemukan satu siswa yang membolos, dan ini menjadi pertanyaan besar bagi kami ada masalah apa pada siswa tersebut. Berdasarkan informasi dari guru BK kami ketahui bahwa memang satu siswa ini di tengarai oleh guru BK ada permasalahan dalam keluarga yang menyebabkan siswa tersebut sering membolos.

\section{PEMBAHASAN}

Secara umum siswa di SMPN 2 Pare dalam satu kelas tersebut aktif dan semangat dalam belajar tetapi, masih ada satu siswa yang bolos sekolah dan malas belajar karena suatu masalah, oleh karena itu pihak sekolah meminta kami untuk memberikan motivasi agar teman-temannya yang lain tidak tertular ikut ikutan membolos. Muatan program yang paling penting dalam kegiatan pengabmas ini adalah memberikan motivasi kepada siswa dengan menanamkan kesadaran dan tanggung jawabnya sebagai siswa sehingga mereka menjadi sadar dan bersemangat dalam belajar demi meraih masa depannya.

Materi yang diberikan meiputi

\section{Tanggung jawab siswa}

di sekolah seperti mengerjakan tugas, patuh terhadap guru, menghormati guru, datang tepat waktu, memakai seragam sekolah,tidak mencontek, jujur.

2. Tanggungjawab sebangai umat beragama

menghormati umat beragama lain, rajin ibadah,tidak rasis, menghormati pemuka agama,menghargai umat beragama lain.

\section{Tanggung Jawab Terhadap Diri Sendiri}

orang yang terbiasa melakukan tanggung jawabnya dengan rela maka tidak akan kesulitan untuk melakukan tanggung jawab lainnya. Oleh karena itu, sebagai remaja yang akan menjadi orang dewasa, harus belajar bertanggung jawab karena salah satu ciri manusia dewasa adalah bertanggung jawab.

4. Tanggung Jawab Terhadap Keluarga

jika kita melaksanakan tanggung jawab sebagai anggota keluarga, berarti pada diri kita ada dorongan untuk meringankan dan memberi kebahagiaan pada semua anggota keluarga. Salah satu penyebab timbulnya konflik antara anak dan orang tua adalah dilalaikannya tanggung jawab, baik pada tugas sebagai anggota keluarga maupun tugastugas untuk kepentingan diri sendiri.

\section{Tanggung Jawab Sebagai Siswa Di Sekolah}

seorang siswa yang bertanggung jawab akan menunjukkan kecintaannya pada sekolah dengan selalu berusaha disiplin, baik dalam perkataan maupun tingkah lakunya. Semua ini akan tercermin dari cara berpakaian, cara berhadapan dengan guru, keseriusan dalam 


\section{Journal of Community Engagement in Health}

mengikuti mata pelajaran, cara berhubungan dengan atau warga sekolah lainnya, serta perilakunya yang jauh dari hal-hal negatif yang membahayakan diri dan lingkungannya. Menjadi siswa yang bertanggung jawab itu menyenangkan dan membanggakan. Kita tentu bangga kepada siswa yang memiliki prestasi dalam bidang akademis. selalu mengerjakan tugas sekolah, disiplin dalam peraturan dan tidak pernah membolos.

\section{Tanggung Jawab Sebagai Anggota Masyarakat}

selain tertib di jalan raya, tanggung jawab terhadap masyarakat dan lingkungan sekitar juga diwujudkan dalam bentuk bagaimana kita menjalin hubungan yang baik dengan tetangga, aktif dalam kegiatan sosial, dan ikut serta dalam menjaga keamanan. Misalnya: bertegur sapa ketika bertemu dengan tetangga, membantu orang yang tertimpa bencana,membuang sampah pada tempatnya, atau melaporkan tamu yang akan menginap di rumah kita. Seluruh bentuk tanggung jawab tersebut bertujuan untuk menciptakan peraturan dan keamanan dalam masyarakat.

\section{Tanggung Jawab Sebagai Umat Beragama}

komunitas religius mengurangi tindakan-tindakan penuh resiko. Remaja aktif dalam kegiatan keagamaan memiliki resiko yang lebih kecil untuk terkena pengaruh negatif pergaulan, seperti penggunaan obat-obatan terlarang, pergaulan bebas, minum-minuman keras, atau bahkan keinginan untuk bunuh diri, dibandingkan dengan remaja yang tidak bergabung dengan komunitas keagamaan.

Semua siswa tampak menyambut dengan baik kehadiran kami disana mereka tampak semangat dan serius mendengarkan motivasi yang kami berikan. Pada akhir sesi kami berikan kesempatan bagi siswa untuk bertanya, hal inipun disambut dengan baik oleh hampir sebagian besar siswa, mereka dengan semangat menyampaikan pendapat, menyampaikan ide - idenya untuk belajar dengan giat, dan yang lebih penting lagi mereka mempunyai tujuan yang jelas guna mewujudkan cita - citanya. Hal ini sesuai dengan teori Penetapan Tujuan (Goal Setting) oleh Edwin Locke (1968) yang mengemukakan bahwa dalam penetapan tujuan memiliki empat macam mekanisme motivasional yaitu :

1) Tujuan - Tujuan mengarahkan perhatian

2) Tujuan - tujuan mengarahkan upaya

3) Tujuan - tujuan meningkatkan persistensi

4) Tujuan - tujuan menunjang strategi - strategi dan rencana kegiatan

Pembelajaran yang efektif bukan membuat siswa menjadi pusing akan tetapi bagaimana tujuan peambelajaran dapat tercapai dengan mudah dan menyenangkan.

Namun selain Kondisi tersebut diatas ditengarai ada siswa yang malas belajar dan membolos ini bila tidak segera ditangani dikhawatirkan akan mengganggu siswa lainnya, meskipun tidak menutup kemungkinan ada permasalahan lain diluar sekolah dalam hal ini masalah keluarga (orang tua) dengan siswa. Ternyata setelah kami lakukan pendekatan bersama guru BK secara mendalam bahkan dengan bertemu langsung dengan orang tua siswa (bapak) dan juga siswa yang terkesan malas belajar dan membolos tersebut kami ketahui bahwa kedua orang tua siswa sama - sama bekerja, berangkatnya pagi dan pulangnya sore bahkan sampai malam karena keduanya selain bekerja juga aktif sebagai pembina dalam kegiatan keagamaan, untuk bapaknya selain pembina keagamaan diluar juga sebagai pembina keagamaan bagi siswa di SMP tersebut. Karena kondisi tersebut maka orang tua siswa yaitu bapaknya berinisiatip untuk membelikan anaknya/siswa tersebut kuota internet yang harapannya anaknya bisa belajar lewat internet dengan tenang dan bisa mengisi waktu dengan bermain game saat menunggu kedua orangtuanya pulang. Kondisi inilah yang menurut kami (penulis dan guru BK) yang menjadi sebab 


\section{Journal of Community Engagement in Health}

http://jceh.org

ISSN: 2620-3758 (print); 2620-3766 (online)

https://doi.org/10.30994/jceh.v3i2.65

Vol.3 No.2. Sep 2020. Page.189-193

permasalahan siswa tersebut muncul, dimana anak dibiarkan main game terus menerus sampai larut malam bahkan lupa waktu yang akhirnya pagi hari malas untuk bangun dan malas bersekolah karena ngantuk berat, ini terjadi berulang ulang tanpa adanya evaluasi dari orang tua.

Dengan adanya permasalahan satu siswa tersebut diatas yang kami temukan, maka kami sebagai pemberi motivasi kepada siswa menyerahkan sepenuhnya permasalahan tersebut kepada orang tua dan pihak sekolah karena orang tua dari siswa tersebut juga sebagai pembina agama di sekolah tersebut. Kami menyadari kondisi ini bukan ranah kami.

\section{KESIMPULAN}

Pemberian motivasi belajar pada siswa SMP sangat penting dilakukan karena mereka memasuki fase baru dalam kehidupannya yaitu masa remaja awal, pada masa ini banyak terjadi perubahan dalam diri remaja yang perlu adanya pengawasan. Motivasi belajar diberikan melalui ceramah tentang bagaimana menjalankan tugas sebagai siswa dengan baik, bahagia dan menyenangkan, siswa dapat mengikuti dengan baik serta mengetahui tanggungjawab dan tugas-tugas sebagai pelajar serta bisa merencanakan masa depannya. Sebagai saran dari kami kepada pihak sekolah agar selalu memantau dan selalu memperhatikan siswa terutama perilakunya selama di sekolah serta memberikan bimbingan yang rutin dengan baik dan bila perlu bekerja sama dengan pihak terkait yang bisa memberikan motivasi belajar kepada siswa.

\section{REFERENSI}

Marilyn M. Friedman., Bowden, V.R., dan Jones, 2010. Buku ajar keperawatan keluarga riset teori dan praktik. EGC. Jakarta.

Notoatmodjo, S. (2010). Ilmu Perilaku Kesehatan. Jakarta: Rineka Cipta.

Rizali, Ervin.2010.hypno healing. Yogyakarta:leutika

Aunurrahman. (2010). Belajar dan Pembelajaran. Bandung: Alfabeta.

Arsyad, Azhar. (2011). Media Pembelajaran. Jakarta: Rajawali Pers.

Hosnan, M. (2014). Pendekatan Saintifik dan Kontekstual dalam Pembelajaran Abad 21. Bogor: Ghalia Indonesia.

Kompri. (2016). Motivasi Pembelajaran Perspektif Guru dan Siswa. Bandung: PT Rosda Karya.

Rajin, M. 2018.Tehnik Pelaksanaan Relaksasi Spiritual. FIK Unipdu Jombang. 